\title{
Photovoltaic Characteristics of Low-density Concentration GaAs Solar Cells with/without Anti-reflective Coating
}

\author{
Sam Kyu Noh ${ }^{a_{*}}$, Jong Soo Kim ${ }^{b}$, Jin Soo $\mathrm{Kim}^{\mathrm{c}}$, and Jae Su Yu ${ }^{\mathrm{d}}$ \\ ${ }^{a}$ Nano Materials Evaluation Center, Korea Research Institute of Standards and Science, Daejeon 305-340 \\ ${ }^{b}$ Department of Physics, Yeungnam University, Gyeongsan 712-749 \\ ${ }^{c}$ Divsion of Advanced Materials Engineering, Chonbuk National University, Jeonju 561-756 \\ ${ }^{d}$ Department of Electronics and Radio Engineering, Kyung Hee University, Yongin 446-701 \\ (Received January 8, 2014, Revised January 21, 2014, Accepted January 21, 2014)
}

We have studied photovoltaic characteristics of single-junction GaAs solar cells with/without an $\mathrm{MgF}_{2} / \mathrm{ZnS}$ anti-reflective coating (ARC) illuminated by low-density concentration $(<10$ suns). By the ARC deposition, the short-circuit current density $\left(\mathrm{J}_{\mathrm{SC}}\right)$ and the fill factor (FF) are increased by $5 \mathrm{~mA} / \mathrm{cm}^{2}$ and $5 \%$ at a standard illumination (1 sun), respectively, and the resulted conversion efficiency is enhanced by $45 \%$. In contrast with the cell with no ARC showing a rapid degradation with increasing concentration power, the efficiency of ARC-deposited cell remains almost constant as $(17.7 \pm 0.3) \%$ regardless of the concentration. It informs that ARC treatment is very effective in GaAs concentrator solar cells.

Keywords : Solar cell, GaAs, Low-density concentration, Conversion efficiency

\section{Introduction}

It is widely known that solar cells converting the solar energy to an electric power are not only proenvironmental but highly efficient energy-reproductive devices [1]. Although the solar cell technology have made significant progress in a past few decades, there is still a lack of the conversion efficiency that would greatly benefit by the power applications [2,3]. Up to date, a number of researches has been accomplished competitively with each other for higher cell efficiency by using various material systems, such as Si, GaAs, CIGS (CuInGaSe), DSSC (dye-sensitive solar cell) [4-7]. Though the world record of 40.7\% (240 suns) [7] was recently achieved by a GaAs-based concentrator solar cell, the challenge toward a theoretical limit of $63.1 \%$ [8] is now being continued. (For reference, very recently, Solar Junction Co. announced $43.5 \%$ (400 suns) over the existing record on March 2012 that was approved by the National Renewable Energy Laboratory.)

GaAs compound semiconductor is one of the most suitable materials for solar cells that has a bandgap $\left(E_{g}=1.42 \mathrm{eV}, 300 \mathrm{~K}\right)$ closest to an optimum energy of $1.4 \mathrm{eV}$, and that is ruled by high-efficient direct transition contrary to $\mathrm{Si}$ with an indirect bandgap. The GaAs system has some advantages that make possible tandem devices stacked by their heterostructures [7], and concentrator solar cells available up to $\sim 1,000$ suns in contrast to $\mathrm{Si}$-based cells with

\footnotetext{
* [E-mail] sknoh@kriss.re.kr
} 
inherent limit in concentration [9-11]. Recently, an exotic mechanism of the multiple exciton generation (MEG) by a single photon has been proposed as a trial to overcome the Shockley-Queisser limit [12-15]. Many studies are focused on the intermediate band (IB) of an advanced base of MEG, and expanded to quantum-dot based solar cells (QSCs) whose sublevels would play a decisive role in MEG [14-16]. Although the highest efficiency achieved by QSCs currently remains at $\sim 20 \%$, it is expected to reach to $25-30 \%$ if an inherent problem of carrier trap into QDs would be solved by realization of IB and MEG [17-24].

In this study, we investigate the effect of antireflective coating (ARC) [25-28] on concentration characteristics in the matrix solar cell as a preceding study of InAs/GaAs concentrator QSCs. We employ double-stacked $\left[\mathrm{MgF}_{2} / \mathrm{ZnS}\right]$ for an ARC layer and a pair of GaAs solar cells with/without ARC. The refractive index of ARC is analyzed by a spectroscopic ellipsometry, and a homemade concentrator module with a position-variable Fresnel lens is applied to the cells for concentration characteristics ( $<10$ suns). The ARC effect and the concentration dependences of solar parameters are discussed.

\section{Experimental Procedures}

A single $\mathrm{p}-\mathrm{n}$ junction GaAs solar cell structure was prepared by a molecular beam epitaxy (MBE) growth system, as sketched in Fig. 1(a). A 1.5- $\mu \mathrm{m}$-thick $\mathrm{n}$-GaAs:Si $\left(2 \times 10^{17} \mathrm{~cm}^{-3}\right)$ base was grown on $\mathrm{n}^{+}-\mathrm{GaAs}$ (100) buffer layer, and a 50-nm-thick $\mathrm{Al}_{\mathrm{x}} \mathrm{Ga}_{1-\mathrm{x}} \mathrm{As}$ : $\mathrm{Be}(\mathrm{x}=0.9)$ window was inserted between $\mathrm{p}^{+}-\mathrm{GaAs}: \mathrm{Be}$ $\left(2 \times 10^{18} \mathrm{~cm}^{-3}, 600 \mathrm{~nm}\right)$ emitter and $\mathrm{p}$-contact layer $(10 \mathrm{~nm})$. A double-stacked $\left[\mathrm{MgF}_{2} / \mathrm{ZnS}\right]$ ARC layer was deposited on the top surface by a thermal evaporator. Standard photolithography was applied to the device fabrication, and the cell dimension used in this study
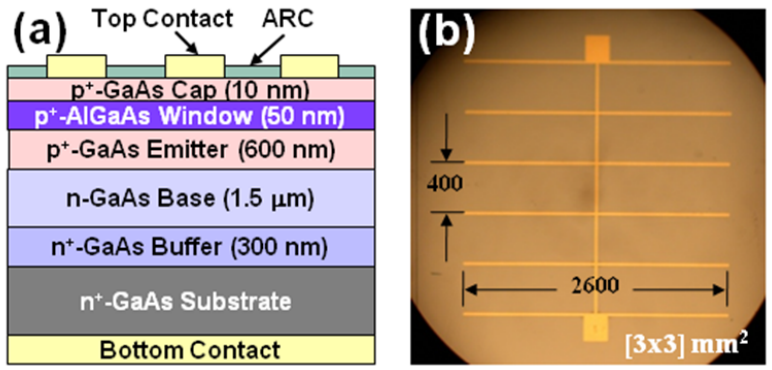

Figure 1. (a) Schematic layer structure of single $p-n$ junction GaAs solar cells, and (b) device configuration of a single cell $\left([3 \times 3] \mathrm{mm}^{2}\right)$ with six 2,600-nm-long fingers at intervals of $200 \mathrm{~nm}$.

is $[3 \times 3] \mathrm{mm}^{2}$. The mesa cell was defined by a chemical etchant of [citric acid: $\left.\mathrm{H}_{2} \mathrm{O}=20: 1\right](\sim 85 \mathrm{~nm} / \mathrm{s})$, and a mixture of $[\mathrm{HCl}+\mathrm{HF}]$ was used for ARC etching. Ohmic contacts for $\mathrm{n}$ - and $\mathrm{p}$-type GaAs were formed by and $\mathrm{Au} / \mathrm{Ge} / \mathrm{Ni} / \mathrm{Au}(26 / 54 / 15 / 200 \mathrm{~nm})$ and $\mathrm{Au}-\mathrm{Zn} /$ $\mathrm{Ni} / \mathrm{Au}(80 / 15 / 200 \mathrm{~nm})$, followed by rapid thermal annealing at $375^{\circ} \mathrm{C}$ and $200^{\circ} \mathrm{C}$, respectively. Fig. 1(b) shows the device configuration of a single cell $([3 \times 3]$ $\mathrm{mm}^{2}$ ) that is composed of six 2,600-nm-long fingers at intervals of $200 \mathrm{~nm}$.

A commercial solar simulator (AM1.5) was employed in measurements for dark and illuminated current-voltage (I-V) curves. For the concentration characteristics under low-density illumination to 10 $\mathrm{P}_{\mathrm{o}}\left(\mathrm{P}_{\mathrm{o}}=100 \mathrm{~mW} / \mathrm{cm}^{2}\right)$, a homemade concentrator module with a position-variable Fresnel lens ( $\mathrm{f}=22 \mathrm{~cm})$ driven by a linear gear/step motor assembly was utilized with the simulator. The concentration density was controlled by focusing the solar source, and primarily calibrated by a solar power meter (TES-1333R) and a neutral density filter (1\%). Sample chuck used in this experiment was designed to keep the cell temperature constant by operating a thermo-electric cooler with a thermocouple. The temperature error was within $\pm 5^{\circ} \mathrm{C}$ for a measurement duration $(\sim 30 \mathrm{~s})$ in atmospheric environment. 


\section{Results and Discussion}

\section{Characteristics of $\left[\mathrm{MgF}_{2} / \mathrm{ZnS}\right]-\mathrm{ARC}$}

Fig. 2 shows (a) surface AFM images $\left(1 \times 1 \mu \mathrm{m}^{2}\right)$ and (b) thickness profiles (Dectak 150) of two individual $\mathrm{MgF}_{2}$ and $\mathrm{ZnS}$ layers and a double-stacked $\left[\mathrm{MgF}_{2} / \mathrm{ZnS}\right]$ layer introduced in this study. As plotted in Fig. 2(b), thicknesses of individual $\mathrm{MgF}_{2}$ and $\mathrm{ZnS}$ layers are $110 \mathrm{~nm}$ and $40 \mathrm{~nm}$, respectively, and that of $\left[\mathrm{MgF}_{2} / \mathrm{ZnS}\right]$ is $130 / 40 \mathrm{~nm}$. A $20-\mathrm{nm}$ addition in thickness of $\mathrm{MgF}_{2}$ deposited on $\mathrm{ZnS}$ is due to the morphological change, as featured in Fig. 2(a). Considering an elongation of the c-axis parameter due to lattice mismatch, $\mathrm{MgF}_{2}$ layer grown on $\mathrm{ZnS}$ is ex-
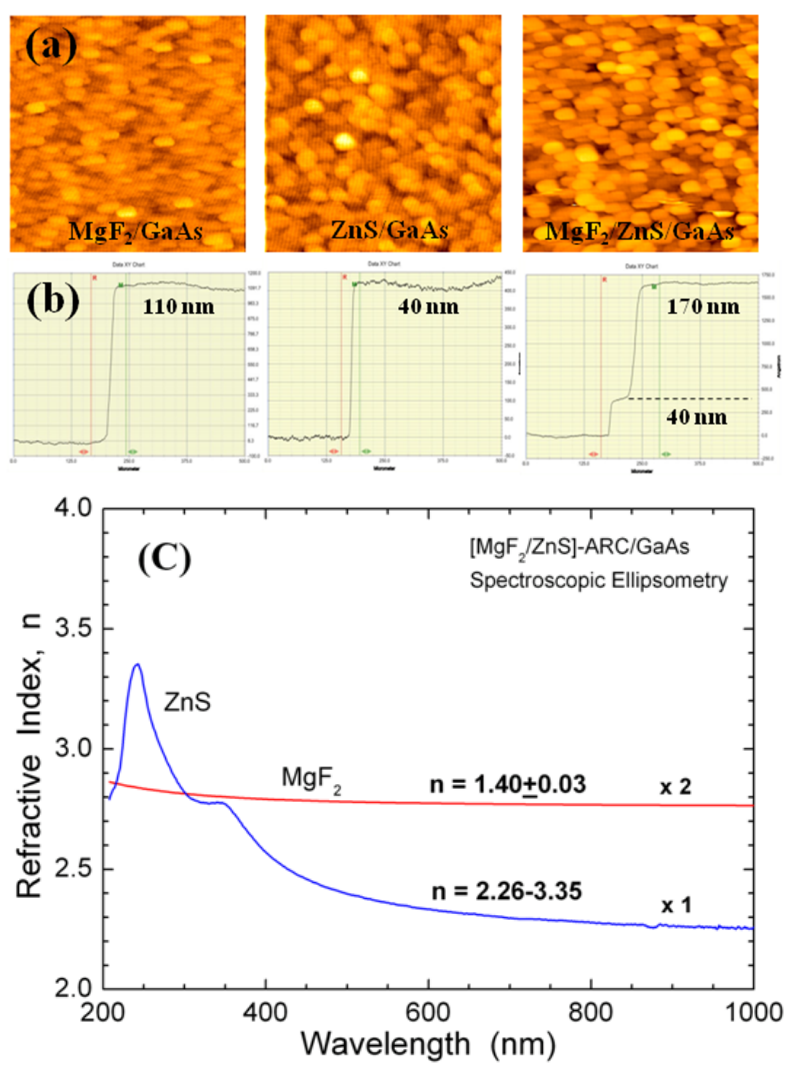

Figure 2. (a) Surface AFM images and (b) thickness profiles of two individual $\mathrm{MgF}_{2}$ and $\mathrm{ZnS}$ layers and a double-stacked $\left[\mathrm{MgF}_{2} / \mathrm{ZnS}\right]$ layer. (c) Refractive index ( $\mathrm{n}$ ) curves of $\mathrm{MgF}_{2}$ and ZnS analyzed by a spectroscopic ellipsometry pected to be thicker than that grown on GaAs. (The lattice parameter of $\mathrm{ZnS}(0.54102 \mathrm{~nm})$ is smaller by $4.3 \%$ than that of GaAs (0.56533 nm) [29].)

Fig. 2(c) presents the refractive index (n) curves of $\mathrm{MgF}_{2}$ and $\mathrm{ZnS}$ analyzed by a spectroscopic ellipsometry. It is confirmed that a pair of spectra simulated from the signal taken from a double-stacked $\left[\mathrm{MgF}_{2} / \mathrm{ZnS}\right]$ layer exactly coincides with those obtained from individual $\mathrm{MgF}_{2}$ and $\mathrm{ZnS}$ layers, and the values of 1.39 $\left(\mathrm{MgF}_{2}\right)$ and 2.31 (ZnS) for a wavelength of $650 \mathrm{~nm}$ are the same as known values. While the index of $\mathrm{ZnS}$ has a peak value $(\mathrm{n}=3.35)$ at $241 \mathrm{~nm}$ and gradually approaches to $n=2.26$ with increasing wavelength, the index of $\mathrm{MgF}_{2}$ remains almost constant as $\mathrm{n}=1.40 \pm 0.03$ in the measurement range $(\lambda=200 \sim$ $1,000 \mathrm{~nm})$. Anti-reflective wavelength for an ARC layer with a thickness $(\mathrm{t})$ can be calculated by the destructive interference condition of $\lambda=4 \mathrm{nt}$ at perpendicular incidence. The effective wavelengths estimated for $\mathrm{MgF}_{2}(\mathrm{t}=130 \mathrm{~nm})$ and $\mathrm{ZnS}(\mathrm{t}=40 \mathrm{~nm})$ used in this study are $700 \mathrm{~nm}$ and $360 \sim 540 \mathrm{~nm}$, respectively. It indicates that low-index $\mathrm{MgF}_{2}$ and high-index ZnS are mostly effective on anti-reflection at central wavelength $(\sim 700 \mathrm{~nm})$ and short wavelength $(<540 \mathrm{~nm})$ of the absorption range of GaAs (420 $870 \mathrm{~nm}$ ). (Refer to Fig. 3(a) for the spectral photoresponse of GaAs solar cell.)

\section{Characteristics of GaAs solar cells}

A typical photoresponse spectrum taken from a GaAs $\mathrm{p}-\mathrm{n}$ junction solar cell is shown in Fig. 3(a) in comparison with a simulated one for the same structure. They clearly show that the cutoff wavelength is about $870 \mathrm{~nm}$ corresponding to the bandgap energy of GaAs $(1.42 \mathrm{eV})$. Differently from the simulated data gradually changing near $400 \mathrm{~nm}$, the experimental curve shows a saturating behavior, which is due to a detection limit of the measurement system used in this study. Fig. 3(b) is the current den- 
sity-voltage $(\mathrm{J}-\mathrm{V})$ characteristic curves taken at a standard illumination $\left(\mathrm{P}_{\mathrm{O}}\right)$ for the solar cells with/ without ARC. The short-circuit current density $\left(\mathrm{J}_{\mathrm{SC}}\right)$ is largely enhanced by $5 \mathrm{~mA} / \mathrm{cm}^{2}(\sim 30 \%)$ by ARC deposition, which is higher than a simulated value (no ARC). It shows that the effect of ARC is crucial
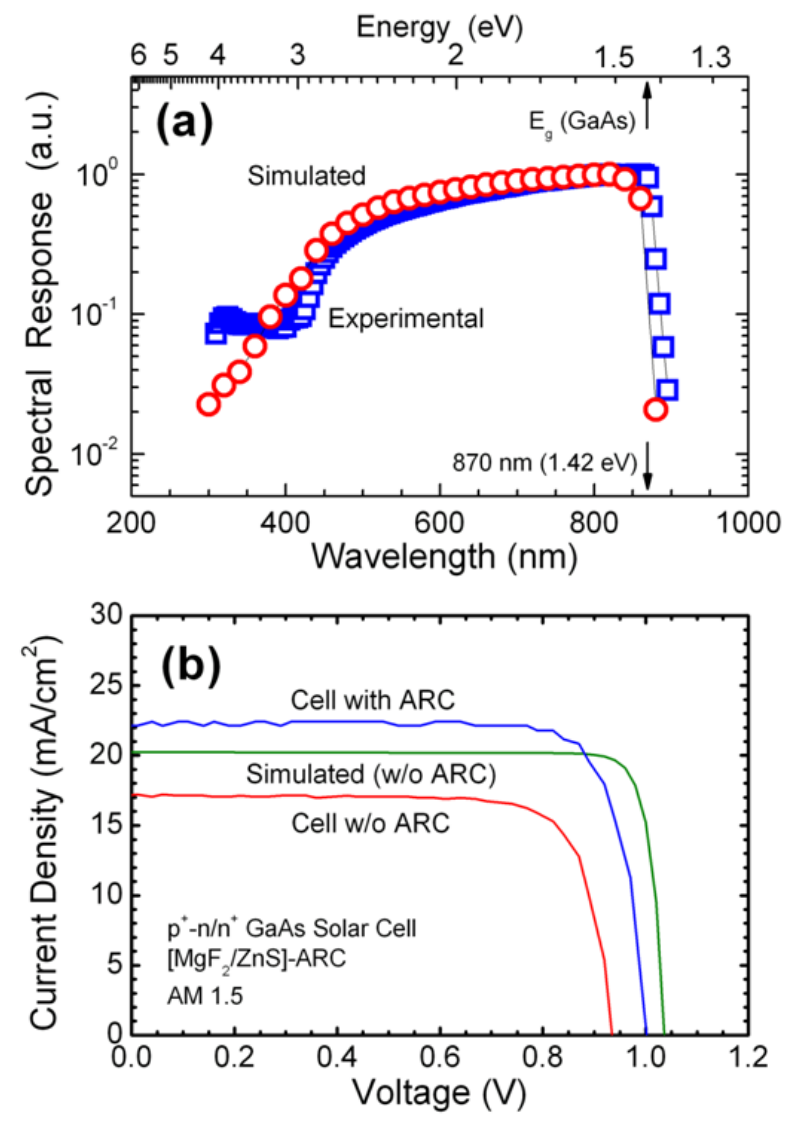

Figure 3. (a) Photoresponse spectra measured and simulated for a GaAs $p-n$ junction solar cell. (b) J-V characteristic curves for GaAs solar cells with/without ARC taken at a standard illumination $\left(\mathrm{AM} 1.5, \mathrm{P}_{\mathrm{O}}=100 \mathrm{~mW} / \mathrm{cm}^{2}\right)$. in GaAs cells with highly reflective surface. Table 1 is a summary on the device parameters analyzed from GaAs $\mathrm{p}-\mathrm{n}$ junction solar cells with/without ARC and the simulated ones.

The concentration characteristics were investigated for the identical cells under low-density illumination ( $<10$ suns). Fig. 4 shows (a) four representative nominal (unnormalized) J-V curves for the ARC-de-
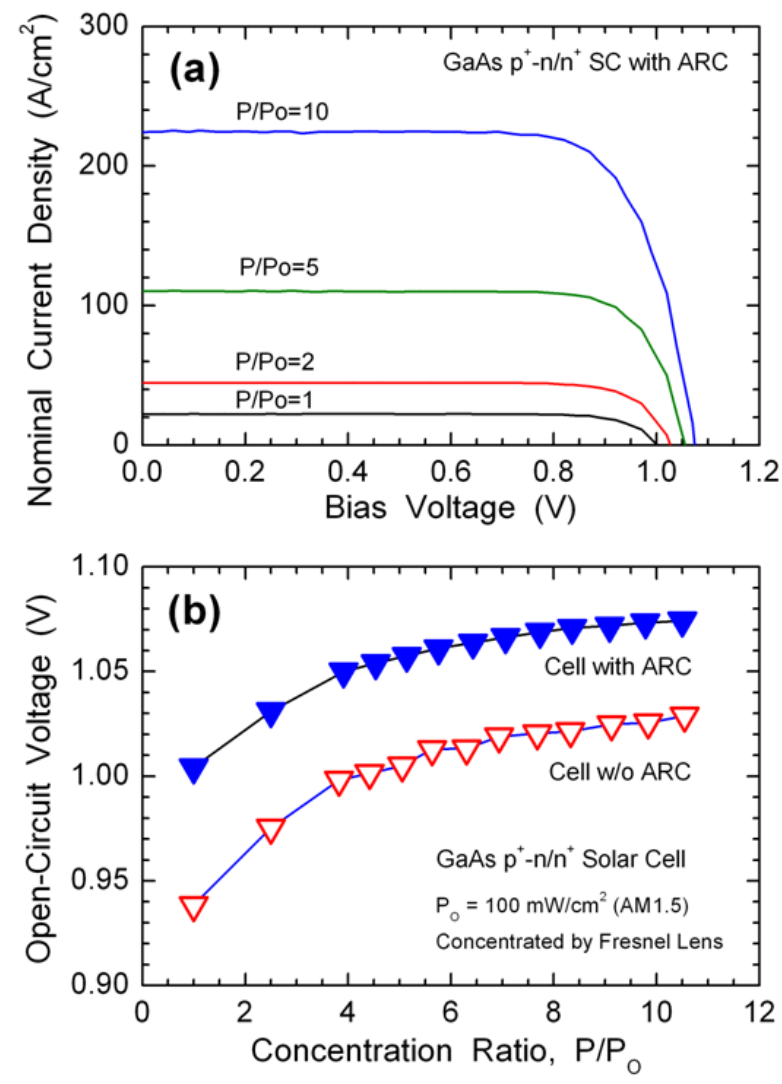

Figure 4. (a) Four representative unnormalized J-V curves for the ARC-deposited cell, and (b) plots of $V_{O C}$ for the cells with/without $A R C$ as a function of concentration ratio $(\mathrm{P} / \mathrm{PO})$.

Table 1. Summary of the solar parameters measured at $100 \mathrm{~mA} / \mathrm{cm}^{2}$ (AM 1.5) for GaAs cellswithout/with ARC and the simulated values.

\begin{tabular}{|c|c|c|c|c|c|}
\hline \multirow{2}{*}{\multicolumn{2}{|c|}{ Samples }} & \multicolumn{4}{|c|}{ Solar cell parameters } \\
\hline & & \multirow{2}{*}{$\frac{\mathrm{V}_{\mathrm{OC}}(\mathrm{V})}{0.938}$} & \multirow{2}{*}{$\frac{J_{\mathrm{SC}}\left(\mathrm{mA} / \mathrm{cm}^{2}\right)}{17.2}$} & \multirow{2}{*}{$\begin{array}{c}\text { Fill factor }(\%) \\
78.0\end{array}$} & \multirow{2}{*}{$\frac{\text { Efficiency }(\%)}{12.6}$} \\
\hline W:th $\triangle D C$ & Experimental & & & & \\
\hline VILHOUL AIV & Simulated & 1.04 & 20.3 & 88.1 & 18.5 \\
\hline With ARC & Experimental & 1.00 & 22.1 & 81.4 & 18.1 \\
\hline
\end{tabular}


posited cell and (b) a pair of plots for the open-circuit voltage $\left(\mathrm{V}_{\mathrm{OC}}\right)$ of the cells with/without ARC as a function of the concentration power. Here, the concentration ratio $\left(\mathrm{P} / \mathrm{P}_{\mathrm{O}}\right)$ is the value of $\mathrm{J}_{\mathrm{SC}}(\mathrm{P}) / \mathrm{J}_{\mathrm{SC}}\left(\mathrm{P}_{\mathrm{O}}\right)$, the nominal $\mathrm{J}_{\mathrm{SC}}(\mathrm{P})$ measured at a power density $(\mathrm{P})$ divided by $\mathrm{J}_{\mathrm{SC}}\left(\mathrm{P}_{\mathrm{O}}\right)$ for non-concentrated condition $\left(\mathrm{P}_{\mathrm{O}}=100 \mathrm{~mW} / \mathrm{cm}^{2}\right)$. Regardless of ARC, two plots show that $\mathrm{VOC}$ gradually grows with increasing $\mathrm{P} / \mathrm{P}_{\mathrm{O}}$. $\mathrm{V}_{\mathrm{OC}}$ at $\mathrm{P} / \mathrm{P}_{\mathrm{O}}=10$ is enhanced by $\sim 7 \%$ comparing with that at $\mathrm{P} / \mathrm{P}_{\mathrm{O}}=1$, which results from multiplication of the nominal current density as demonstrated in Fig. 4(a).

The $\mathrm{P} / \mathrm{P}_{\mathrm{O}}$ dependence of the fill factor $(\mathrm{FF})$ is presented in Fig. 5(a). As the ratio increases, the FF value of the cell with no ARC rapidly falls but that of the ARC-deposited cell slowly decreases. The decrease of $\mathrm{FF}$ comes from a serial resistance increasing with the diode current density. As shown in $\mathrm{J}-\mathrm{V}$ curves of Fig. 4(a), the curve's knee that the current
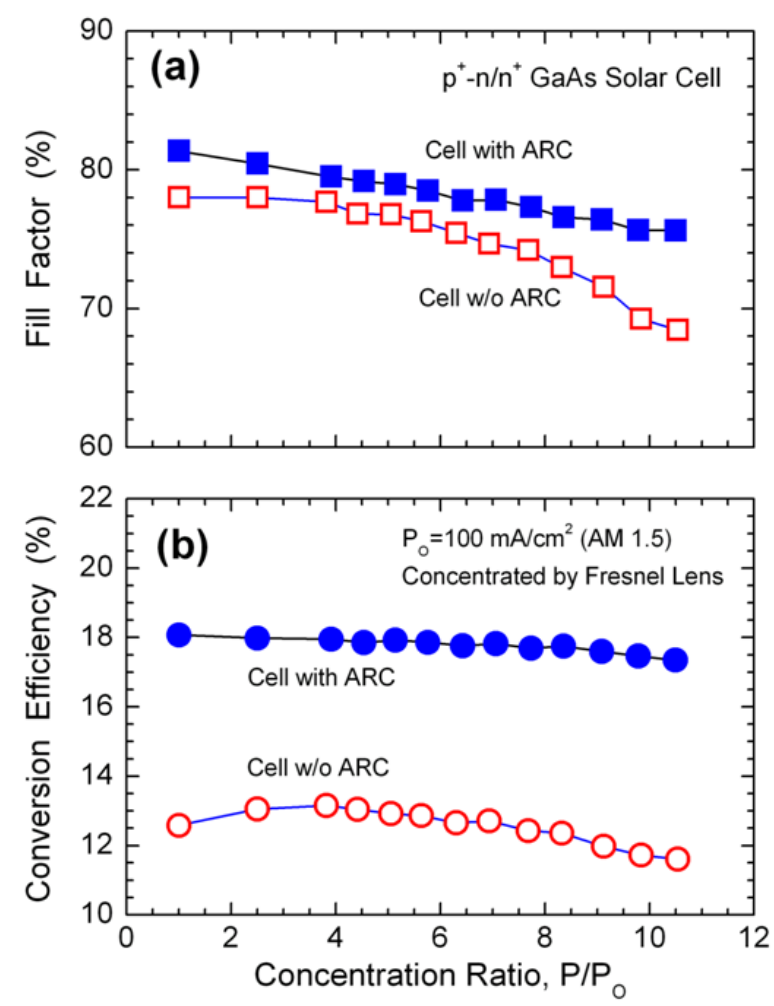

Figure 5. Plots of (a) FF and (b) $\eta$ for the cells with/without ARC as a function of concentration ratio $\left(\mathrm{P} / \mathrm{P}_{\mathrm{O}}\right)$. density begins to drop becomes blunter due to serial resistance increasing with the concentration ratio. The rapid degradation shown in the cell with no ARC may be attributed to involvement of the carrier recombination occurring in unpassivated devices in addition to the resistance. It informs that ARC layer plays important roles not only in the surface reflection but in the carrier recombination.

The data plotted in Fig. 5(b) are the conversion efficiency $(\eta)$ estimated from the values of $\mathrm{V}_{\mathrm{OC}}$ and $\mathrm{FF}$ presented in Figs. 4 (a) and 4(b) by using the equation below;

$$
\eta=\mathrm{P}_{\text {Out }} / \mathrm{P}_{\text {In }}=\mathrm{FF} \times\left[\left(\mathrm{J}_{\mathrm{SC}} / \mathrm{P}_{\mathrm{In}}\right) \times \mathrm{V}_{\mathrm{OC}}\right]
$$

Here, $\mathrm{P}_{\mathrm{In}}$ is the input solar power density illuminated by the simulator, and $\mathrm{P}_{\text {Out }}$ is the output electric power density generated by the cell under test, $\mathrm{FF} \times$ $\left[J_{S C} \times V_{O C}\right]$. The factor of $\left(J_{S C} / P_{\text {In }}\right)$ in Eq. $(1), J_{S C}$ normalized to the input power density, has a constant value as $22.1 / 17.2 \mathrm{~mA} / \mathrm{cm}^{2}$ for the cells with/without ARC. Two curves indicate that the efficiency is enhanced by $5 \sim 6 \%$ by ARC deposition, and the difference becomes larger with increasing concentration power. In addition, the solar cell does not exhibit any improvement in the conversion efficiency by lowdensity concentration due to increase of serial resistance. However, they clearly demonstrate the effect of $\left[\mathrm{MgF}_{2} / \mathrm{ZnS}\right]-\mathrm{ARC}$ in GaAs solar cells with highly reflective surface and a limit of single-junction structures [5].

\section{Summary and Conclusions}

We have characterized the spectroscopic refractive index of a double-stacked $\left[\mathrm{MgF}_{2} / \mathrm{ZnS}\right]-\mathrm{ARC}$ layer and the solar parameters of single-junction GaAs solar cells with/without ARC for low-density concentration ( $<10$ suns). The ellipsometric spectra showed that 
the refractive index of $\mathrm{MgF}_{2}$ remained almost constant as $n=1.40 \pm 0.03$ in the range of $\lambda=200 \sim 1,000$ $\mathrm{nm}$, and that of $\mathrm{ZnS}$ gradually decreased to $\mathrm{n}=2.26$ $(\lambda \sim 1,000 \mathrm{~nm})$ from a peak value $(\mathrm{n}=3.35, \quad \lambda=241$ $\mathrm{nm})$. It informed that ARCs of low-index $\mathrm{MgF}_{2}$ and high-index ZnS used in this study were effective on anti-reflection at central wavelength $(\sim 700 \mathrm{~nm})$ and short wavelength $(<540 \mathrm{~nm})$ of the absorption range of GaAs, respectively.

The short-circuit current density $\left(\mathrm{J}_{\mathrm{SC}}\right)$ and the fill factor $(\mathrm{FF})$ of GaAs solar cells were enhanced by 5 $\mathrm{mA} / \mathrm{cm}^{2}$ and $5 \%$ by ARC deposition at a standard illumination (1 sun), respectively, and the resulted efficiency $(\eta)$ was increased by $45 \%$. The efficiency of the cell with no ARC rapidly decreased with increased concentration power, but that of the $\mathrm{ARC}$-deposited cell almost remained constant at $(17.7 \pm 0.3) \%$. It as sured that the ARC treatment considerably enhanced the device performance of GaAs solar cell with highly reflective surface, especially under the concentration environment that the carrier recombination became dominated.

\section{Acknowledgements}

This work was supported by the National Research Foundation (NRF) of Korea Grant funded by the Korean Government (MEST) (NRF-2009-C1AAA0010093212/253).

\section{References}

[1] J. Nelson, The Physics of Solar Cells (Imperial College Press, London, 2003).

[2] F. Dimroth and S. Kurtz, MRS Bull. 32, 230 (2007).

[3] M A. Green, K. Emery, Y. Hishikawa, and W. Warta, Prog. Photovol: Res. Appl. 18, 144 (2010).
[4] J. -W. Kang, C. -H. Son, G. -S. Cho, J. H. Yoo, J. -S. Kim, C. -K. Park, and G. -C. Kwon, J. Korean Vac. Soc. 21, 62 (2012).

[5] K. -S. Lee, Y. D. Chung, N. M. Park, D. H. Cho, K. H. Kim, J. Kim, S. J. Kim, Y. Kim, and S. K. Noh, J. Opt. Soc. Korea 14, 321 (2010).

[6] F. O. Lenzmann and J. M. Kroon, Advancies in OptoElectronics 2007, 10 (2007).

[7] R. R. King, D. C. Law, K. M. Edmondson, C. M. Fetzer, G. S. Kinsey, H. Yoon, R. A. Sherif, and N. H. Karam, Appl. Phys. Lett. 90, 183516 (2007).

[8] A. Luque and A. Marti, Phys. Rev. Lett. 78, 5014 (1997).

[9] B. Galiana, I. Rey-Stolle, M. Baudrit, I. Garcia, and C. Algora, Semicond. Sci. Technol. 21, 1387 (2006).

[10] A. Khan, M. Yamaguchi, and T. Takamoto, Appl. Phys. Lett. 85, 3098 (2004).

[11] M. -J. Yang and M. Yamaguchi, Sol. Ener. Mater. Sol. Cells 60, 19 (2000).

[12] R. D. Schaller, M. Sykora, J. M. Pietryga, and V. I. Kilmov, Nano Lett. 6, 424 (2006).

[13] M. C. Beard, K. P. Knutsen, P. Yu, J. M. Luther, Q. Song, W. K. Metzger, R. J. Ellingson, and A. J. Nozik, Nano Lett. 7, 2506 (2007).

[14] A. Luque and A. Marti, Phys. Adv. Mater. 22, 160 (2010).

[15] S. P. Bremner, M. Y. Levy, and C. B. Honsberg, Appl. Phys. Lett. 92, 171110 (2008).

[16] A. Marti, E. Antolin, E. Canovas, N. Lopez, P. G. Linares, A. Luque, C. R. Stanley, and C. D. Farmer, Thin Solid Films 516, 6716 (2008).

[17] Y. Okada, R. Oshima, and A. Takata, J. Appl. Phys. 106, 024306 (2009).

[18] C. G. Bailey, D. V. Forbes, R. P. Raffaelle, and S. M. Hubbard, Appl. Phys. Lett. 98, 163105 (2011).

[19] D. Zhou, P. E. Vullum, G. Sharma, S. F. Thomassen, R. Holmestad, T. W. Reenaas, and B. O. Fimland, Appl. Phys. Lett. 96, 083108 (2010). 
[20] D. Guimard, R. Morihara, D. Bordel, K. Tanabe, Y. Wakayama, M. Nishioka, and Y. Arakawa, Appl. Phys. Lett. 96, 203507 (2010).

[21] K. A. Sablon, J. W. Little, K. A. Olver, Zh. M. Wang, V. G. Dorogan, Yu. I. Mazur, G. J. Salamo, and F. J. Towner, J. Appl. Phys. 108, 074305 (2010).

[22] K. A. Sablon, J. W. Little, V. Mitin, A. Sergeev, N. Vagidov, and K. Reinhardt, Nano Lett. 11, 2311 (2011).

[23] T. Gu, M. A. El-Emawy, K. Yang, A. Stintz, and L. F. Lester, Appl. Phys. Lett. 95, 261106 (2009).

[24] C. Y. Ngo, S. F. Yoon, W. K. Loke, T. K. Ng, S. J. Chua, J. Cryst. Growth 311, 1885 (2009).
[25] S. J. Tark, M. G. Kang, S. Park, J. H. Jang, J. C. Lee, W. M. Kim, J. S. Lee, and D. Kim, Curr. Appl. Phys. 9, 1318 (2009).

[26] J. W. Leem and J. S. Yu, Opt. Express 20, 26160 (2012).

[27] Y. H. Ko, M. S. Kim, and J. S. Yu, J. Korean Vac. Soc. 20, 381 (2011).

[28] D. -Y. Kong, D. -H. Kim, S. -H. Yun, Y. -H. Bae, I. -S. Yu, C. -S. Cho, and J. -H. Lee, J. Korean Vac. Soc. 20, 233 (2011).

[29] S. Adachi, Properties of Group-IV, III-V and II-VI Semiconductors (John Wiley \& Sons, Chichester, 2005), p. 7. 